\title{
The induction and needs of beginning teacher educators
}

\author{
Citation for published version (APA):
}

Van Velzen, C., Van der Klink, M., Swennen, A., \& Yaffe, E. (2010). The induction and needs of beginning teacher educators. Professional Development in Education, 36(1/2), 61-75.

https://doi.org/10.1080/19415250903454817

\section{DOI:}

$10.1080 / 19415250903454817$

Document status and date:

Published: 04/11/2010

Document Version:

Peer reviewed version

\section{Document license:}

CC BY

Please check the document version of this publication:

- A submitted manuscript is the version of the article upon submission and before peer-review. There can be important differences between the submitted version and the official published version of record. People interested in the research are advised to contact the author for the final version of the publication, or visit the DOI to the publisher's website.

- The final author version and the galley proof are versions of the publication after peer review.

- The final published version features the final layout of the paper including the volume, issue and page numbers.

Link to publication

\section{General rights}

Copyright and moral rights for the publications made accessible in the public portal are retained by the authors and/or other copyright owners and it is a condition of accessing publications that users recognise and abide by the legal requirements associated with these rights.

- Users may download and print one copy of any publication from the public portal for the purpose of private study or research.

- You may not further distribute the material or use it for any profit-making activity or commercial gain

- You may freely distribute the URL identifying the publication in the public portal.

If the publication is distributed under the terms of Article 25fa of the Dutch Copyright Act, indicated by the "Taverne" license above, please follow below link for the End User Agreement:

https://www.ou.nl/taverne-agreement

Take down policy

If you believe that this document breaches copyright please contact us at:

pure-support@ou.nl

providing details and we will investigate your claim.

Downloaded from https://research.ou.nl/ on date: 26 Apr. 2023 


\title{
The induction and needs of beginning teacher educators
}

\author{
Corinne van Velzen ${ }^{\mathrm{a} *}$, Marcel van der Klink ${ }^{\mathrm{b}}$, Anja Swennen ${ }^{\mathrm{a}}$ \\ and Elka Yaffe ${ }^{\mathrm{c}}$ \\ ${ }^{\mathrm{a}}$ VU University Amsterdam, The Netherlands; ${ }^{\mathrm{b}}$ Open University Heerlen, \\ The Netherlands; ${ }^{\mathrm{C}}$ Oranim College of Education, Israel
}

\begin{abstract}
This article presents the results of an exploratory research study into induction practices of novice teacher educators in six different countries. The study was a project carried out by members of the Association of Teacher Educators Europe (ATEE) Research and Development Centre Professional Development of Teacher Educators. Induction is seen as a process of becoming a teacher educator and encompasses two levels. Firstly, it refers to the organizational induction into the teacher education institute. Secondly, it is about becoming a member of the profession (professional induction). Data were gathered through semi-structured interviews with 11 beginning teacher educators. The findings indicated that induction is quite problematic. None of the teacher educators experienced a satisfying induction into their institute and the profession as well. The article concludes with recommendations for improvement of induction practices and further research. This collaborative research project also revealed a lack of shared language in communicating professional issues and the need to further develop this within international communities like the ATEE.
\end{abstract}

\section{Introduction}

Within the Association of Teacher Educators Europe (ATEE), the Research and Development Centres (RDCs) — which are similar to Special Interest Groups-focus on collaborative projects and research. In this paper we present a study based on the research of the RDC 'Professional Development of Teacher Educators'. The members of this RDC are experienced teacher educators in colleges and universities in various European countries and Israel, Australia and North America. The authors of this article all are members of the RDC Professional Development of Teacher Educators.

*Corresponding author. VU University, CETAR, De Boelelaan 1105, $1081 \mathrm{HV}$, Amsterdam, The Netherlands. Email: c.vanvelzen@ond.vu.nl

ISSN 1941-5257 (print)/ISSN 1941-5265 (online)/10/01-20061-15

(C) 2010 International Professional Development Association (IPDA)

DOI: $10.1080 / 19415250903454817$ 
This article was downloaded by: [Open Universiteit]

On: 3 November 2010

Access details: Access Details: [subscription number 921482639]

Publisher Routledge

Informa Ltd Registered in England and Wales Registered Number: 1072954 Registered office: Mortimer House, 3741 Mortimer Street, London W1T 3JH, UK

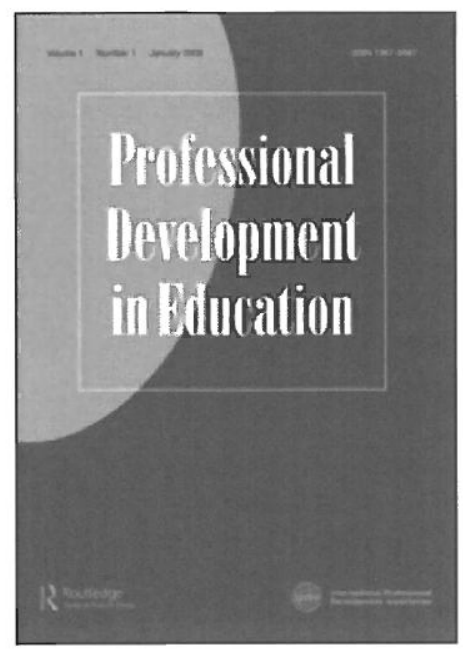

\section{Professional Development in Education}

Publication details, including instructions for authors and subscription information:

http://www.informaworld.com/smpp/title $\sim$ content=t716100715

\section{The induction and needs of beginning teacher educators}

Corinne van Velzen ${ }^{\mathrm{a}}$; Marcel van der Klink ${ }^{\mathrm{b}}$; Anja Swennen ${ }^{\mathrm{a}}$; Elka Yaffe

${ }^{a}$ VU University Amsterdam, The Netherlands ${ }^{b}$ Open University Heerlen, The Netherlands ${ }^{c}$ Oranim

College of Education, Israel

Online publication date: 15 February 2010

To cite this Article van Velzen, Corinne, van der Klink, Marcel, Swennen, Anja and Yaffe, Elka(2010) 'The induction and needs of beginning teacher educators', Professional Development in Education, 36: 1, $61-75$

To link to this Article: DOI: $10.1080 / 19415250903454817$

URL: http://dx.doi.org/10.1080/19415250903454817

\section{PLEASE SCROLL DOWN FOR ARTICLE}

Full terms and conditions of use: http://www.informaworld.com/terms-and-conditions-of-access.pdf

This article may be used for research, teaching and private study purposes. Any substantial or systematic reproduction, re-distribution, re-selling, loan or sub-licensing, systematic supply or distribution in any form to anyone is expressly forbidden.

The publisher does not give any warranty express or implied or make any representation that the contents will be complete or accurate or up to date. The accuracy of any instructions, formulae and drug doses should be independently verified with primary sources. The publisher shall not be liable for any loss, actions, claims, proceedings, demand or costs or damages whatsoever or howsoever caused arising directly or indirectly in connection with or arising out of the use of this material. 